\title{
The impact of supply chain capability and supply chain performance on marketing performance of retail sectors
}

\author{
Elimawaty Rombe ${ }^{\mathrm{a}^{*}}$ and Suryadi Hadi ${ }^{\mathrm{a}}$
}

${ }^{a}$ Department of Management, Faculty of Economics and Business, Tadulako University, Indonesia

\section{A B S T R A C T}

\section{Article history:}

Received September 19, 2021

Received in revised format

October 24, 2021

Accepted November 172021

Available online

November 182021

Keywords:

Supply chain capability

Supply chain performance

Marketing performance

\begin{abstract}
To increase competitive advantage, any company needs to improve its supply chain management. The aim of this study is to define the relationships between supply chain capability, supply chain performance and marketing performance. Some of the retail stores are no longer operating. Tool of analysis is the partial least square that is suitable for small sample size. The result of PLSSmart 3.0 shows that the relationship between supply chain capability and supply chain performance is positive and significant. However, the relationship between supply chain performance and marketing performance is positive but non-significant. Direct relationship between supply chain capability and marketing performance appears to be positive and significant. Indirect relationship between supply chain capability and marketing performance through supply chain performance also appears to be non-significant. The study can be a reference for retail managers to increase the supply chain in their marketing performance. Some further research needs to add other variables to see a more concrete relationship between supply chain capability and marketing performance.
\end{abstract}

(c) 2022 Growing Science Ltd. All rights reserved.

\section{Introduction}

The trade sector plays an important role in the economic activities of a country, especially for most developing countries. Trade activity is one of the driving forces of economic growth so that it becomes an indication of the prosperity level of the society. Indonesia is a developing country that has a growing population and purchasing power, resulting in enormous market potential and attracts businessmen both from within and from abroad to enter and develop the market. Many new companies are emerging and enliven the business competition in Indonesia. By that, the trade sector became the second contributor after the agricultural sector in the absorption of labor in Indonesia. One form of business from the trade sector that is quite promising is the business of retail business. Retail business in Indonesia, especially, experienced a rapid development. Shift lifestyle from traditional to modern lifestyle opens opportunities for retailers. Retail is one of the retail businesses that has good prospects that attract interests not only from local businessmen but also foreigners. Currently urban hamsters prefer to shop in retail than traditional markets. In addition to the more convenient facilities, cool and clean, retail also provides a complete household needs so that consumers can freely choose some type of household needs in just one shopping area only. But the problem that often occurs in retail in the city of the hammer inventory system is less good. Sometimes the product consumers want is not available or commonly called stock-out. Running out of this inventory can cause consumers to switch to another retail store.

According to Makisurat et al. (2014) inventory is a very important element for every company such as manufacturing companies and trading companies since inventory is the main source of revenue in realizing and improving corporate profits. A trading company may be defined as an organization conducting business by purchasing goods from other parties or

* Corresponding author

E-mail address: elimawatyrombe.untad@gmail.com (E. Rombe)

(C) 2022 Growing Science Ltd. All rights reserved.

doi: $10.5267 /$ j.uscm.2021.11.005 
companies and reselling them to the public either in the form of retail or wholesale and distributors. People are increasingly careful in choosing, assessing, and comparing each retail store when they do shopping. Every self-service is required to be more responsive to consumer needs and market demand with a good and efficient inventory system. A poor inventory system will impact on unmet customer demand. This will lead to a loss of opportunity to earn profits that should be obtained.

Providing prompt and timely service and a good and efficient inventory system, each retailer must find the right supplier, and build trust with the right partner because it has a big impact on current and future business performance. To achieve these multi-criteria objectives, it has become imperative for organizations or companies worldwide to utilize the concept of supply chain management (Haryotejo \& Kusumawardhani, 2015; Quyen, 2020). Supply Chain Management (SCM) is a network of companies that work together to create and deliver a product into the hands of the end user (Nupus \& Ichwanudin, 2021). These companies usually include suppliers, manufacturers, distributors, stores, or retailers, as well as support companies such as logistics services (Pujawan, 2005; Mughal, 2019). The importance of the role of all parties ranging from suppliers, manufacturers, distributors, retailers, and customers in creating a cheap, quality, and fast products is what later gave birth to a new concept of supply chain management (Pujawan \& Mahendrawati, 2010; Tanwari, 2020; Wahyuni \& Praninta, 2021).

Currently, SCM has become a very important competitive advantage for companies to provide fast service with a variety of products and high quality with low cost, so the company can still exist during increasingly fierce competition and higher cost levels. Therefore, companies should be able to improve the performance of SCM (Budiman, 2013; Sobar et al., 2021). This study aims to determine the relationship between supply chain capabilities, supply chain performance and marketing performance. Based on the literature search results obtained the result that research that discusses the supply chain capability (supply chain capability) is still very less. According to the literature search results also obtained a positive relationship related to the supply chain ability of supply chain performance to marketing performance.

\section{Literature Review}

\subsection{Supply Chain Management and Capability}

Kotler and Keller (2016) define supply chain as a channel that extends from raw materials to components until the finished product is brought to the final buyer. Each company in the chain captures only a certain percentage of the total value generated by the supply chain value delivery system. When a company acquires a competitor or expands upstream or downstream, the goal is to capture a higher percentage of supply chain value. According to Siahaya (2013), SCM is the integration of competent business sources both inside and outside the company to obtain a competitive supply system and focuses on synchronizing product and information flows to create high customer value. Integrated business sources include suppliers, manufacturers, warehouses, transporters, distributors, retailers, and consumers who work efficiently so that the products produced and distributed meet the right quantity, quality, time and location. In terms of supply chain capability, Morash (2001) conducted a study that connected the influence of supply chain strategy, capabilities and company performance and concluded that the relationship between the three variables was very significant. Based on this study, it is found that supply chain capability is highly dependent on several things, namely: 1) customer service; 2) quality; 3) support information systems; 4) distribution flexibility; 5) low logistics costs; 6) productivity; 7) delivery speed. There are three dimensions of supply chain operational capabilities including structural, logistics and technology (Hadi \& Parubak, 2016). Previous studies found that marketing and supply chain operational capability have significant impact on business performance (Muslimin et al., 2017; Riswanto, 2021). Providing training is also a critical role in supply chain management because it will lead to sustainability (Muslimin et al., 2021).

\subsection{Supply Chain Performance and Marketing Performance}

There are several indicators in the literature and in business organizations that are recommended to use in measuring the performance of SCM systems (Folan \& Browne, 2005). However, several attempts have been made to determine the minimum number or set of indicators required to measure the performance of an SCM system with maximum effectiveness and minimum operating costs (Gunasekaran \& Kobu, 2007). Other studies have shown that supply chains lack accurate performance indicators for comparison, benchmarking and decision making (Aramyan et al., 2007). Traditionally, companies have tracked performance based on financial accounting principles, which date back to ancient Egypt and Phoenicia (Bora et al., 2004). Performance-based measures include previous researchers: Balanced Scorecard; the Supply-Chain Operations Reference (SCOR) model; Logistics Scoreboard; Activity-Based Costing (ABC) and Economic Value Analysis (EVA). Regarding marketing performance, it is a description of the level of achievement of the implementation of tasks in an organization, to realize the goals, objectives, mission, and vision of the organization. To measure the company's performance can be done by measuring financial performance, operational performance, and market-based performance. Marketing performance is expressed in three main quantities, namely: First, sales volume, namely the volume or number of product sales successfully achieved by the company. Second, customer growth, namely the level of customer growth that was successfully achieved by the company. Third, profitability, namely the amount of profit from product sales that have been obtained by the company (Ratnawati, 2013). 


\subsection{Hypothesis Development}

The ability of SCM to quickly change according to the needs of output or work to be done. The level of flexibility required by each SCM is different and highly dependent on their competitive strategy in the market. SCM flexibility is determined by many factors such as procurement flexibility, production flexibility, and shipping flexibility. Another thing to be considered by retail is that they should be able to manage quality in the supply chain is the integration of the quality philosophy of the supplier quality system, the internal system of the firm profitable point and the quality that customers expect. Some quality indicators include a formal quality assurance system, continuous improvement, statistical process control, six sigma limit, fail-safe traceability and acceptable quality (Hugo et al., 2004). The expected outcome of the supplier performance evaluation process is to identify suppliers with outstanding performance or development needs, improve supplier communications, reduce risk and manage partnerships based on analysis (Wisner et al., 2012). Suppliers' ability to provide goods or products needed by self-service will help them improve supply chain performance. Supply chain responsiveness refers to how quickly the supply chain delivers products to customers (Cohen \& Rousell, 2005). This involves the elapsed time from customer orders received until delivery is complete (Johnson, 2008). Lead time order fulfillment is an important measure of supply chain response and measures the number of days from receipt of customer service orders to delivery receipts at customer premises (Bolstorff \& Rosenbaum, 2003). An average delivery period of goods that will be long enough will affect selfservice in improving supply chain performance. Supply chain asset management refers to the organization's effectiveness in managing assets to support demand satisfaction (Taylor, 2004). This includes the management of all assets (Bolstorff \& Rosenbaum, 2003). Three indicators that measure the efficiency of supply chain asset management are cash-to-cash cycle times, inventory days and asset turn. The top organizations have a cash-to-cash cycle time of approximately 30 days (Wisner et al., 2012). Based on the results of research on retail in obtaining the conclusion that good enough supply chain capability will affect supply chain performance. Thus, the first hypothesis is proposed as follows:

\section{H1: There is a significant influence of supply chain capability to supply chain performance.}

According to Banerjee and Mishra (2015) other factors that could affect the supply chain on retail performance in India are a competitive advantage. Based on this, this research needs to be continued by connecting the variables of competitive advantage with self-service performance especially in terms of marketing performance. The presence of a new retail, which is a branch of a large retail business in Indonesia, is very influential on the level of marketing and sales of retail that have been running this business within a bracket of about a decade (Thahir et al., 2018). The most important thing in marketing activities is the high ability to provide services that can satisfy the customers (Soetjipto et al., 2021). The ability of supply chain in terms of customer service is one of the priorities so that it can directly support the marketing performance of increasing sales volume. Another ability of the supply chain that supports marketing performance is the support of information systems that assist the retail in the process of planning and ordering products so that it can become more effective and efficient. Another thing that supports marketing activities at retail is the delivery reliability of supply chain activities in delivering the right product to the right place at the right time in the right conditions and correct packing with the correct documentation (Cohen \& Rousell, 2005). Reliability generally refers to the ability to produce a product when promised (Wang et al., 2007).

Another ability of the supply chain that can improve marketing performance is the flexibility that the self-service gets in getting the shipment properly. Suppliers are very flexible in establishing distribution channels to help the retail in obtaining the desired goods or products. Suppliers are also very helpful self-service in choosing the right method of transportation for goods or products ordered according to customer needs. Similarly, the problem of delivery time felt by the retail is greatly helped by their suppliers. This is a very helpful marketing activity conducted by retailers or retail shops.

\section{H2: There is a significant effect of supply chain performance on marketing performance.}

The ability of suppliers in improving their productivity is very influenced in marketing activities. Supplier operating standards will also affect the performance of retail in marketing products or goods. Simple ordering standards are helpful to self-service in ordering products or items to be sold to their customers. The same is true of the speed at which the average delivery time from the industrial center takes less than a week after ordering. The retail industry generally thinks that the delivery of goods from suppliers to the retail runs smoothly. Based on this, the performance of self-service marketing can increase. But the ability to maintain the quality of goods ranging from the source of delivery or suppliers to the retail as a customer is still low. The results of this study indicate that quality aspects of supply chain capability variables have a low loading factor. This illustrates that the ability of supply chain in retail is still one of the problems that can affect the improvement of supply chain capability. The negative impact of high logistics costs is the increase of inventory in the warehouse because retailers tend to order products or goods with a lot to the supplier to reduce logistics costs. Another thing that may influence the extent to which logistics cost indicator support for supply chain capability is the inability of employers to determine what items are contained in logistics costs. Their research results prove that the logistics cost data aspect is the most difficult thing determined by the business actor if associated with the supply chain.

\section{H3: There is a significant influence of supply chain capability to marketing performance.}


Morash (2001) conducted a study linking the influence of supply chain strategy, capability and firm performance and concluded that the relationship between the three variables was significant. Morash (2001) also emphasized two sides of the supply chain: supply and demand. On the supply side the focus of the relationship between supply chain capabilities on firm performance is directed at cost, productivity, distribution and speed factor. While the demand side the focus of the relationship between capability and performance of the company is directed to customer service and quality. One of the new self-service advantages is that they already have an integrated supply chain. This is generally still difficult to be followed by self-service based so that they can be defeated in future business competition. The negative impact that can result from this condition is that retail that have been operating long enough may not be able to compete so they will stop operating. In general, integration in the supply chain is strongly supported by the availability of good information systems. Supply chains are in dire need of exchanging information so that every entity (stakeholders) in the supply chain can make the right decisions and not affect all entities involved in the supply chain. In general, the logistics cost aspect in the supply chain also affects the performance of the supply chain, which has an impact on marketing and sales. Therefore, supply chain capability greatly influences supply chain performance, but marketing performance is not influenced by supply chain performance at retail (Santra et al, 2019).

\section{H4: There is a moderating effect of supply chain capability to marketing performance through supply chain performance.}

\section{Research Methods}

This research type is explanatory research by using quantitative approach. explanatory research is a research method that intends to explain the position of the variables studied and the influence of one variable with another variable. The population in this study is retails that operates in a small town in Indonesia, such as Palu. The total of retails operate is 85 units in the area of study, but the sample size of this study was 30 respondents. The respondents have position as manager or owner. Variables in this study consist of the independent (supply chain capability), intervening (supply chain performance) and bound (marketing performance). Statistical analysis tool used in this research is Partial Least Square (PLS) model. PLS analysis is one of the methods currently used to cover the existing weaknesses of the regression method with the Variance Based SEM approach. According to Ghozali (2006), PLS is a soft modeling analysis method because it does not assume the data should be with a certain scale measurement, which means the number of samples can be small under 100 samples. The fundamental difference between PLS which a variance-based SEM with LISREL or Covariance-based AMOS is the purpose of its use. Compared to covariance-based SEM (represented by AMOS software, LISREL and EQS) component based PLS can avoid two major problems faced by covariance-based SEM that is inadmissible solution and factor indeterminacy. PLS analysis uses SmartPLS, which is run with computer media. Analysis on PLS is done by three stages: outer model evaluation, inner model evaluation and bootstrapping evaluation.

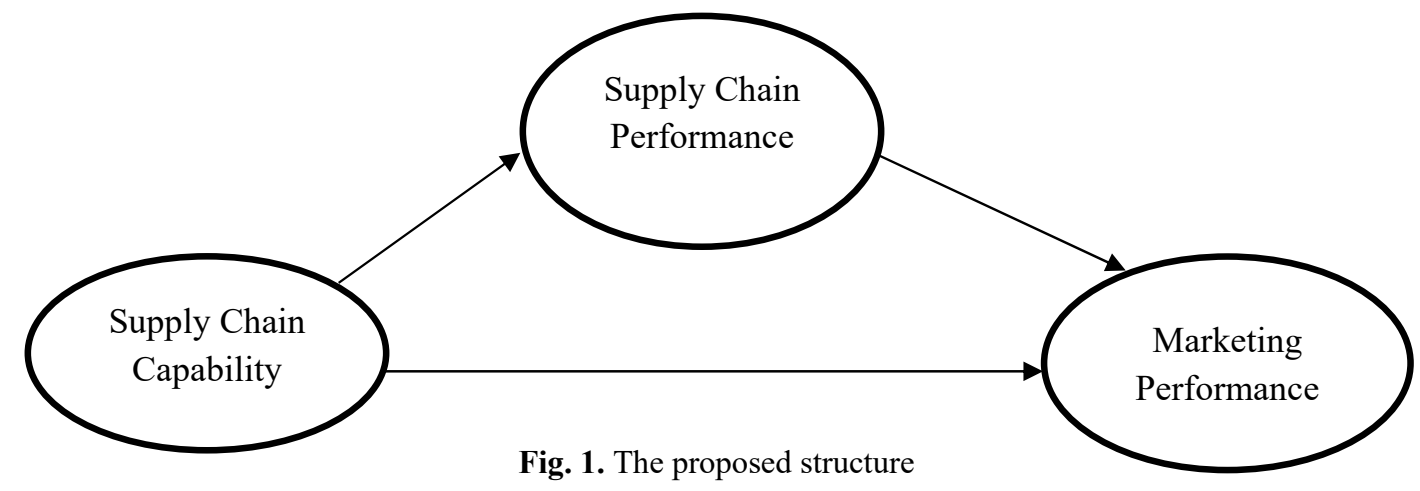

\section{Results and Discussion}

\subsection{Empirical Testing}

The results show that all variables have AVE value above 0.5 so it can be said that all constructs have met the discriminant validity value or have a good validity value. The CR value of all variables is above 0.7 or it can be said that all variables have met the composite reliability value or have good reliability. Nunnaly (1996) stated that the research variable that has a CR $>$ 0.70 means that the measured variable has good reliability. Meanwhile, the value of Cronbach's alpha of all variables shows a value above 0.6 , so it can be concluded that all the variables measured have good reliability. The results of the hypothesis are accepted if t-statistic greater than 1,701. Based on Table 2, the first hypothesis testing that the effect of supply chain capability (SCC) to supply chain performance (SCP) shows the value of the coefficient path of 0.686 with a value of t-statistic 6,461. This means that SCC has a positive and significant influence on SCP. This result is consistent with the first hypothesis in which supply chain ability can contribute to improved supply chain performance and the first hypothesis is accepted. The result of second hypothesis testing that influences supply chain performance (SCP) to marketing performance (MP) shows coefficient value of path equal to 0,198 with t-statistic 1,217 . This means that SCP has no positive and significant effect on 
MP. This result is inconsistent with the second hypothesis stating that supply chain performance can contribute to improved marketing performance and the second hypothesis is not accepted.

Table 1

Average Variance Extracted (AVE), Composite Reliability, Cronbach's Alpha

\begin{tabular}{lccc}
\multicolumn{1}{c}{ Variable } & $\begin{array}{c}\text { Average Variance } \\
\text { Extracted } \\
\text { (AVE) }\end{array}$ & $\begin{array}{c}\text { Composite Reliability } \\
\text { (CR) }\end{array}$ & Cronbach's Alpha \\
\hline Supply Chain Capability (SCC) & 0.575 & 0.871 & 0.815 \\
Supply Chain Performance (SCP) & 0.634 & 0.873 & 0.806 \\
Marketing Performance (MP) & 0.906 & 0.951 & 0.896 \\
\hline
\end{tabular}

The result of the third hypothesis testing is the effect of supply chain capability (SCC) on marketing performance (MP) shows the coefficient value of the line is 0.612 with a value of t-statistic 8,586 . This means that SCC has a positive influence on MP. This result is compatible with the third hypothesis in which supply chain capability can contribute to improving marketing performance. This means that the third hypothesis is accepted. The results of the fourth hypothesis testing to test the indirect effect of supply chain capability (SCC) variable on marketing performance (MP) through supply chain performance (SCP) is done by first knowing the test result against SCC influence on SCP and SCP to MP. This test is performed using Sobel's formula. The test results show the coefficient value of 0.1358 with a value of t-statistic 0.1149 . This means that SCC has no positive and significant effect on MP through SCP. This result is incompatible with the fourth hypothesis which states that supply chain ability can contribute to improving marketing performance through supply chain performance. This means that hypothesis fourth is rejected.

Table 2

\begin{tabular}{lccccc} 
Coefficient Path & Original (O) & Mean (M) & $\begin{array}{c}\text { Standard } \\
\text { Deviation } \\
\text { Relations }\end{array}$ & $\begin{array}{c}\text { T Statistic } \\
\text { (O)/STDEV) }\end{array}$ & P Values \\
\hline $\mathrm{SCC} \rightarrow \mathrm{MP}$ & 0.612 & 0.762 & 0.087 & 8.586 & 0.000 \\
$\mathrm{SCC} \rightarrow \mathrm{SCP}$ & 0.686 & 0.691 & 0.106 & 6.461 & 0.000 \\
$\mathrm{SCP} \rightarrow \mathrm{MP}$ & 0.198 & 0.222 & 0.163 & 1.217 & 0.224 \\
\hline
\end{tabular}

Source: SmartPLS 3.0 data processing

\subsection{Discussion}

Regarding the influence of supply chain capability to supply chain performance, the results of the first hypothesis testing showed that the relationship between Supply Chain Capability (SCC) and Supply Chain Performance (SCP) variables showed a positive and significant relationship. Supply chain performance is strongly influenced by the ability of self-service in reducing the cost, especially the cost of delivery and all activities that occur on the corner of the supply so that retail need to conduct intensive negotiations because the products or goods ordered imported very far from the place of sale. This is particularly burdensome for retail in reducing costs due to the great distances and complexity of handling goods at some point in the supply chain, making it difficult for logistics companies to provide low cost on every shipment. Another ability that can affect supply chain performance at retail is the ability of the supply chain to consistently deliver on the promise. For example, shipments from suppliers are said to be reliable if the deviation of delivery time is relatively small against the time promised or expected. The ability of the supply chain to provide products or services when needed. For example, inventory availability measures the availability of inventory at times and places where customers need it. Fill rate and customer service level are two examples of metrics that measure availability on the supply chain.

In testing the effect of supply chain performance on marketing performance, the result of the second hypothesis test shows that the relationship between Supply Chain Performance (SCP) and Marketing Performance (MP) does not show a significant relationship. The high level of competition between retail increasingly affects their performance in general and especially marketing performance. Increasing the number of self-service greatly affects the sales growth of some retails. Consumers are increasingly being spoiled for choice or the variety of products offered by new self-service managers at massive discounts. Therefore, how well the supply chain performs, if the capital turnover is strongly influenced by sales also decreased it will have a major impact on marketing performance. In the supply chain, downstream smoothness will greatly affect the upstream activities because in the supply chain all entities are important and interconnected with each other. This is in contrast to previous research that supply chain performance is very influential on business performance where the marketing performance aspect is an integral part therein. Based on the results of research on retail in obtaining the conclusion that supply chain performance (supply chain performance) has no significant effect on marketing performance. Related to the influence of supply chain capability to marketing performance, the result of the third hypothesis testing shows that the relation of Supply Chain Capability (SCC) variable with Marketing Performance (MP) variable shows positive and significant relationship. These results indicate that Supply Chain Capability in assisting marketing performance at retail is very 
influential. This study provides information that logistics costs are still felt very high for retail so that this can affect supply chain capabilities. If linked to the performance of retail marketing, this logistic cost problem can be one cause even if it does not directly affect the marketing performance. Both issues should not be allowed to be resolved, along with those involved in the supply chain so that the supply chain ability on marketing performance at retail can be further improved. Quality issues and logistics costs that become aspects that support supply chain capability should be resolved through meetings between the parties involved to come up with a collective agreement. This is in line with the principle of the supply chain prioritizing collaboration among the parties involved.

The results of the fourth hypothesis test regarding the influence of supply chain capability to marketing performance through supply chain performance show that the relationship between supply chain capability (SCC) and marketing performance (MP) through supply chain performance (supply chain performance) shows no significant relationship. The results of this study indicate that the relationship between supply chain ability to marketing performance through supply chain performance does not show a strong and strong relationship. This is because not all retail implement integration with major suppliers and other entities that support the supply chain, especially logistics companies. This study shows that marketing and sales indicators have no effect in shaping supply chain performance. This is due to the low supply chain ability of retail to influence their business processes in achieving improved marketing performance. This is also caused by other factors that can affect the improvement of the supply chain in this business sector that is increasing the level of competition faced by retailers. Based on the results of research on retail obtained the conclusion that supply chain capability does not significantly affect marketing performance through supply chain performance. This study points to the result that supply chain performance is not enough to help tighten the relationship between supply chain capabilities and marketing performance (Zahara et al., 2021; Rombe et al., 2018).

\section{Conclusions}

Based on the results, supply chain ability has a significant effect on supply chain performance at retail. The findings of this study suggest that supply chain performance is strongly influenced by supply chain capabilities. Supply chain performance does not significantly influence marketing performance at retail. The findings of this study inform that marketing performance is not directly influenced by supply chain performance. Supply chain ability has a significant effect on marketing performance at retail. The results of this study inform that marketing performance is strongly influenced directly by supply chain capability. Supply chain capability has no indirect effect on marketing performance through supply chain performance at retail. The results of this study inform that the relationship between supply chain capability and marketing performance on self-service is not influenced by the mediation variables of supply chain performance. To anticipate such matters and to achieve the purpose and purpose of supply chain role on marketing performance at retail, it is suggested as follows: Retail should maintain supply chain capabilities and supply chain performance to improve marketing performance and the company in general. Integration issues in the supply chain with other entities need to be implemented by retail to maintain company performance. Further research is expected to add the number of respondents and other variables to draw conclusions in general on the ability of the supply chain to the company's performance on self-service.

\section{References}

Aramyan, L. H., Lansink, A. G. O., Van Der Vorst, J. G., \& Van Kooten, O. (2007). Performance measurement in agri-food supply chains: a case study. Supply Chain Management: An International Journal, 12(4), 304-315.

Bolstorff, P., \& Rosenbaum, R. (2003). Supply Chain Excellence: A Handbook for Dramatic Improvement Using the SCOR Model (Third Edition). New York: Amacom.

Bora, A., Chiamsiri, S., \& Krairit, D. (2004). Developing key performance indicators for performance controlling of a supply chain. In Proceedings of the Fifth Asia Pacific Industrial Engineering and Management Systems Conference.

Budiman, E. V. (2013). Evaluasi Kinerja Supply Chain Pada UD Maju Jaya di Desa Tiwoho Kabupaten Minahasa Utara. Jurnal Riset Ekonomi, Manajemen, Bisnis dan Akuntansi, 1(4).

Cohen, S., \& Rousell, J. (2005). Strategic supply chain management: the five disciplines for top performance. New York: McGraw-Hill.

Folan, P., \& Browne, J. (2005). A review of performance measurement: Towards performance management. Computers in Industry, 56(7), 663-680.

Ghozali, I. (2006). Analisis Multivariate Lanjutan dengan Program SPSS (1 Ed). Semarang: Badan Penerbit Universitas Diponegoro.

Gunasekaran, A., \& Kobu, B. (2007). Performance measures and metrics in logistics and supply chain management: a review of recent literature (1995-2004) for research and applications. International journal of production research, 45(12), 28192840 .

Hadi, S., \& Parubak, B. (2016). Supply Chain Operational Capabilities Affecting Business Performance of Creative Industries. Bandung: Advance in Economics, Business and Management Research, vol.15. $1^{\text {st }}$ Global Conference on Business, Management and Entrepreneurship (GCBME-16).

Haryotejo, B., \& Kusumawardhani, A. (2015). Analisis Pengaruh Kinerja Logistik Pemasok Terhadap Kinerja Bisnis (Studi Pada Bengkel AHASS di Kota Semarang). Diponegoro Journal of Management, 4(3), 1-6. 
Hugo, W. M. J., Badenhorst-Weiss, J. A., \& Van Bijlon, E. B. H. (2004). Supply chain management: logistics in perspective ( $3^{\text {rd }}$ ed.). Pretoria: Van Schaik.

Johnson, P. (2008). Logistics and supply chain management. London: McGraw-Hill.

Kotler, P., \& Keller, K. L. (2016). A framework for marketing management. Boston, MA: Pearson.

Makisurat, A., Morasa, J., \& Elim, I. (2014). Penerapan Sistem Pengendalian untuk Persediaan Barang Dagangan pada CV. Multi Media Persada Menado. Jurnal Riset Ekonomi, Manajemen, Bisnis dan Akuntansi, 2(2).

Morash, E. A. (2001). Supply Chain Strategies, Capabilities, and Performance. Transportation Journal, 41(1), 37-54.

Mughal, M. (2019). Impact of green supply chain management practices on performance of manufacturing companies in Jordan: A moderating role of supply chain traceability. Arthatama, 3(2), 67-82.

Muslimin, Mangun, N., Rombe, E., Taqwa, E., Sutomo, M., \& Hadi, S. (2021). AHP structure for determining sustainable performance of Indonesian seafood supply chain from stakeholders' perspective. Journal of Management Information and Decision Sciences. 24(7), 1-10.

Muslimin, Parubak, B., Natsir, M., \& Hadi, S. (2017). The Impact of Marketing and Supply Chain Operational Capabilities on Business Performance in Indonesian Creative Industry. International Journal of Economic Research, 14(12), 133-138.

Nupus, H., \& Ichwanudin, W. (2021). Business Network Accessibility, Customer Relationship Management and Value Cocreation on Family Business Performance. Research Horizon, 1(4), 126-135.

Pujawan, I. N. (2005). Supply Chain Management. Surabaya: Guna Widya.

Pujawan, I. N., \& Mahendrawathi. (2010). Supply Chain Management (2 ${ }^{\text {nd }}$ ed.). Surabaya: Guna Widya.

Quyen, T. (2020). The Relationship between Green Procurement Practices and Organizational Performance in the Manufacturing Industry of Vietnam. Arthatama, 4(1), 1-16.

Ratnawati, A. (2013). Peningkatan kinerja pemasaran melalui optimalisasi keunggulan bersaing. Jurnal Ekonomi dan Bisnis, $14(1), 72-89$.

Riswanto, A. (2021). Competitive Intensity, Innovation Capability and Dynamic Marketing Capabilities. Research Horizon, $1(1), 7-15$

Rombe, E., Vesakha, G., Mustamin, \& Hadi, S. (2018). Application of analytic hierarchy process in determining priorities to reduce food loss and food waste in Indonesia. International Journal of Supply Chain Management, 7(6), 494-499.

Santra, I.K., Widiantara, I.M., \& Prayustika, P.A. (2019). Optimizing capabilities in utilizing resources flexibility to improve the performance of hospitality small and medium-sized enterprises. Quality - Access to Success, 20(173), 68-71.

Siahaya, W. (2013). Sukses Supply Chain Management Akses Demand Chain Management. Jakarta: Media.

Sobar, A., Deni, A., Riswandi, R., Hamidi, D. Z., \& Permadi, I. (2021). The Effect of Product Turnover on Company Performance of SMEs. Research Horizon, 1(3), 115-119.

Soetjipto, N., Kurniawan, G., Sulastri, S., \& Riswanto, A. (2021). The Influence of Employee Discipline, Learning and Supervision on the Service Performance of Public Works in Bina Marga Office of Ponorogo Regency. Research Horizon, 1(4), 143-149.

Tanwari, A. (2020). A Study on Assessing the Relationship between Green Marketing and Brand Loyalty in Manufacturing Sector of Greece: A Moderating Role of Green Supply Chain Practices. Arthatama, 4(1), 44-55.

Taylor, D. A. (2004). Supply Chains: A Manager's Guide. Boston: Addison-Wesley.

Thahir, H., Rombe, E., Ponisri., Vesakha, G., \& Hadi, S. (2018). Analysis of internal risk management in Indonesian seaweed farming. International Journal of Engineering and Technology (UAE), 7(4), 200-203

Wahyuni, S., \& Praninta, A. (2021). The Influence of Brand Equity and Service Quality on Purchase Decisions on Garuda Indonesia Airline Services. Research Horizon, 1(1), 28-38.

Wang, W. Y. C., Heng, M. S. H., \& Chau, P. Y. K. (2007). Supply Chain Management: Issues in the New Era of Collaboration and Competition. Hersey: Idea Group Inc.

Wisner, J. D., Tan, K.-C., \& Leong, G. K. (2012). Principles of supply chain management: a balanced approach. Mason: South-Western Cengage Learning.

Zahara, Z., Rombe, E., Ngatimun, N., \& Suharsono, J. (2021). The effect of e-service quality, consumer trust and social media marketing on intention to use online transportation services. International Journal of Data and Network Science, $5(3), 471-478$. 
(C) 2022 by the authors; licensee Growing Science, Canada. This is an open access article distributed under the terms and conditions of the Creative Commons Attribution (CCBY) license (http://creativecommons.org/licenses/by/4.0/). 